\title{
Validations of high-rank syntaxa in Potamogetonetea and Scheuchzerio-Caricetea fuscae
}

\author{
Jean-Paul Theurillat ${ }^{1}$, Ladislav Mucina ${ }^{2}$ and Michal Hájek ${ }^{3}$
}

\begin{abstract}
Theurillat, J.-P., Mucina, L. \& Hájek, M. Validations of high-rank syntaxa in Potamogetonetea and Scheuchzerio-Caricetea fuscae. Lazaroa 36: 67-73. (2015).

This paper presents the validation of five syntaxonomic concepts -two orders (Callitricho hamulatae-Ranunculetalia aquatilis, Zannichellietalia pedicellatae) and three alliances (Ranunculion aquatilis, Nelumbion nuciferae and Caricion viridulo-trinervis).
\end{abstract}

Keywords: aquatic macrophytic vegetation, Europe, transitional mires.

Resumen: Theurillat, J.-P., Mucina, L. \& Hájek, M. Validaciones de los sintaxones de alto rango de Potamogetonetea y Scheuchzerio-Caricetea fuscae. Lazaroa 36: 67-73. (2015).

En este trabajo se propone la validación de cinco sintaxones, dos órdenes (Callitricho hamulatae-Ranunculetalia aquatilis, Zannichellietalia pedicellatae) y tres alianzas (Ranunculion aquatilis, Nelumbion nuciferae y Caricion viridulo-trinervis).

Palabras clave: Vegetación macrofítica acuática, Europa, vegetación transicional de turberas.

\section{INTRODUCTION}

The aquatic vegetation of fresh waters of the temperate region is quite homogeneous and species poor, in correspondance with a rather selective and uniform habitat colonized by widely distributed taxa. Nevertheless, quite a lot of names have been proposed at the order and alliance levels, especially for the rooted vegetation of the class Potamogetonetea. Curiously enough too, several of the syntaxonomic concepts currently retained in recent national surveys (e.g. SCHAMinéE \& al., 1995) do not have a valid name, even for orders (see MucInA \& al., submitted). In this respect, this paper presents the validation of four syntaxonomic concepts (two orders and two alliances). In addition, one alliance for the transitional mires (Scheuchzerio-Caricetea fuscae) is also validated. This paper was motivated by the synthetic assessment of the European vegetation to be shortly published as the EuroVegChecklist (Mucina \& al., submitted). References to articles of the International Code of Phytosociological Nomenclature (ICPN) follow Weber \& al. (2000). Nomenclature of the taxa follows the Euro+Med PlantBase (http://www.emplantbase.org/home.html) if not indicated otherwise.

\footnotetext{
${ }^{1}$ Centre alpien de Phytogéographie Fondation J.-M. Aubert, CH-1938 Champex-Lac, Switzerland. Section of Biology, University of Geneva, Case postale 60, CH-1292 Chambésy, Switzerland. E-mail: jean-paul.theurillat@unige.ch

${ }^{2}$ Iluka Chair in Vegetation Science and Biogeography, School of Plant Biology, The University of Western Australia, 35 Stirling Hwy, Crawley WA 6009, Perth, Australia. Email: laco.mucina@uwa.edu.au. Department of Geography \& Environmental Studies, Stellenbosch University, Private Bag X1, Matieland 7602, Stellenbosch, South Africa. Department of Botany and Microbiology, College of Science, King Saud University, P.O. Box 2455, Riyadh 11451, Saudi Arabia

3 Department of Botany and Zoology, Masaryk University, Kotláøská 2, CZ-611 37 Brno, Czech Republic. E-mail: hajek@sci.muni.cz
} 


\section{VALIDATIONS OF THE NAMES OF SYNTAXA OF THE POTAMOGETONETEA}

Callitricho hamulatae-Ranunculetalia aquatilis Passarge ex Theurillat ord. nov. hoc loco

(Potamogetonetea)

Synonyms: Parvopotametalia Den Hartog et Segal 1964 p.p.; Callitricho-Batrachetalia Den Hartog et Segal ex Passarge 1978 nom. inval. (ICPN art. 2b); Callitricho-Potametalia Schaminée, Lanjouw et Schipper 1990 nom. inval. (ICPN art. 3b); Callitricho-Potametalia Schipper, Lanjouw et Schaminée in Schaminée, Weeda et Westhoff 1995 nom. inval. (ICPN art. 2b).

TYPE: Holotypus (hoc loco): Ranunculion aquatilis Passarge ex Theurillat in Theurillat et al. 2015 (see below).

DiAGNOSTIC SPECIES OF THE ORDER: Ranunculus aquatilis, $R$. fluitans and $R$. hederaceus.

Syntaxonomy: beside the Ranunculion aquatilis Passarge ex Theurillat 2015 (holotype) the original diagnosis of the order contains also the Batrachion fluitantis Neuhäusl 1959 and the Ranunculion omiophyllo-hederacei Rivas-Mart. et al. 2002.

Nomenclature: The name 'CallitrichoBatrachietalia (Den Hartog et Segal 64) ord. nov.' was published on p. 138 in PASSARGE (1978) and includes two alliances, such as the 'Batrachion fluitantis Neuh. 59' and the 'Batrachion aquatilis Pass. 64'. There is no direct or indirect bibliographical reference to a publication by Neuhäusl in 1959 referring to the 'Batrachion fluitantis'; this alliance contains in PASSARge (1978) only the "AG Batrachietum fluitantis All. 22" (AG means in German 'Assoziationsgruppe', Engl.: 'group of associations'), listing several associations within the AG. The "Assoziationsgruppe" is not recognized as a syntaxonomic rank (ICPN Principle II, art. 3d) and, therefore, the name 'Batrachion fluitantis Neuhäusl ex Passarge $1978^{\prime}$ ' is invalidly published. The other alliance, the 'Batrachion aquatilis Pass. 64', was invalidly published in PASSARge (1964) and it remains so in PASSARge (1978) because the name-giving taxon does not occur in the original diagnosis of any of the four associations forming the original diagnosis of the alliance (ICPN art. 3f). Therefore, the name Callitricho-Batrachietalia Den Hartog et Segal ex Passarge 1978 is also invalidly published (ICPN art. 2b).

On its side, the name 'Callitricho-Potametalia' is also invalidly published, both in Schaminée \& al. (1990: 14) and in SCHAMINÉE \& al. (1995: 99). In 1990, the name is not properly accepted (ICPN art. 3b; "Appropriate would be CallitrichoPotametalia"; translation from the Dutch). In 1995, the name 'Callitricho-Potametalia Schipper, Lanjouw et Schaminée' is published as new. However, the original diagnosis of the name contains only the invalidly published name 'Ranunculion peltati Schaminée, Lanjouw et Schipper 1990’ (ICPN art. 3f; see below).

The name 'Callitricho-Batrachietalia' having not been validly published, we validate it here as Callitricho hamulatae-Ranunculetalia aquatilis selecting the (also here) validated name Ranunculion aquatilis (see below) as the holotypus.

The name-giving species of the genus Callitriche can be only those species that occur in the original diagnosis of the two alliances classified in this order. In the Ranunculion aquatilis there is Callitriche stagnalis, present in the original diagnosis of the Hottonietum palustris Tüxen ex Roll 1940. Callitriche verna is found in the protologue of the Ranunculetum hederacei Schnell 1939 and Callitriche hamulata in the CallitrichoRanunculetum fluitantis Oberdorfer 1957. There is no Callitriche in the Potamogetono perfoliati-Ranunculetum fluitantis Koch 1926, the single element of the diagnosis of the Batrachion fluitantis Neuhäusl 1959.

\section{Ranunculion aquatilis Passarge ex Theurillat all. nov. hoc loco \\ (Callitricho hamulatae-Ranunculetalia aquatilis, Potomogetonetea)}

SynONyms: Ranunculion aquatilis Passarge 1964 nom. inval. (ICPN art. 2b); Callitricho- 
Batrachion Den Hartog et Segal 1964 p.p. nom. superfl. (ICPN arts. 25, 29c); Batrachion aquatilis Passarge 1978 nom. inval. (ICPN art. 3f); Lemno-Callitrichion Passarge 1992 nom. inval. (ICPN art. 3g); Ranunculion peltati Schaminée, Lanjouw et Schipper 1990 nom. inval. (ICPN art. 3f).

TYPE: Holotypus (hoc loco): Ranunculetum aquatilis Géhu 1961 (GÉHU 1961: 100-101).

Diagnostic SPecies: Hottonia palustris, Ranunculus hederaceus, $R$. peltatus subsp. peltatus.

SyntaXonomy: Beside the Ranunculetum aquatilis Géhu 1961 (holotype), the alliance Ranunculion aquatilis Passarge ex Theurillat contains also non controversial associations such as the Hottonietum palustris Tüxen ex Roll 1940 and the Ranunculetum hederacei Schnell 1939.

\section{NOMENClATURE:}

\section{Ranunculion aquatilis/ Batrachion aquatilis}

The name 'Ranunculion aquatilis' in PASSARGE (1964: 15) is invalidly published because the original diagnosis of the alliance contains only two groups of associations ('Assoziationsgruppe'), such as the 'Ass.-Gr. Ranunculetum aquatilis Géhu 61' and the 'Ass.-Gr. Hottonietum palustris Tx. 37'. Since the 'Assoziationsgruppe' is a syntaxonomic rank which is not recognized by the Code (ICPN Principle II, art. 3d), the name 'Ranunculion aquatilis Passarge 1964' is lacking a sufficient diagnosis (ICPN art. 2b, 8) and therefore it is invalidly published (ICPN art. 2b).

The name 'Batrachion aquatilis Pass. 64' in PASSARGE (1978: 138) contains the following four associations: 'Hottonietum palustris Tx. 1937', 'Batrachietum peltati Sauer 47', 'Batrachietum hederacei (Tx. et Diem. 36) Libb. 40' [recte Ranunculetum hederacei Tüxen et Diemont ex Libbert 1940] and 'Batrachietum baudotii Br.-B1. 52'. There are no relevés presented for any of these associations, and there are also no references to the authorities of the associations found in the bibliography. However, the bibliographical reference to PASSARge (1964) forms an indirect bibliographi- cal reference (ICPN, art. $2 \mathrm{~b}$, note 2) where one can find bibliographical references to the original diagnosis of three of these associations, while the last one - the 'Batrachietum peltati Sauer 47' [recte Sauer 1937] - is a phantom as only a bibliographical reference to SAUER (1937) is given where no name 'Batrachietum peltati' occurs. The name giving taxon Batrachium/ Ranunculus aquatilis is missing in the 'Hottonietum palustris prov.' in TÜXEN (1937: 49), in the Ranunculetum baudotii in BRAUN-BLANQUET \& al. (1952: 79), and in the 'Ranunculushederaceus-Assoziation (Tx. et Diemont) Libbert 1940' in LiBBERT (1940: 100-101). Therefore, the name 'Batrachion aquatilis Passarge 1978' is invalidly published (ICPN art. 3f).

\section{Callitricho-Batrachion}

The new alliance 'Callitricho-Batrachion' in Den HARTOG \& SEgAL (1964: 388) contains three associations: 'Callitricheto-Ranunculetum baudotii Den Hartog 1963', 'Hottonietum palustris Tüxen 1937' and 'Ranunculetum fluitantis Allorge 1922' [recte 1921]. For all the three associations there is an unambiguous bibliographical reference. The 'CallitrichetoRanunculetum baudotii' is validly published in Den Hartog (1963: 158). Although the name 'Hottonietum palustris' is published provisionally in Tüxen (1937: 49), it is an accepted name in Den Hartog \& Segal, and thus it is validly published. The name 'Ranunculetum fluitantis' is lacking a sufficient diagnosis (no relevés; art. 2b) and is invalidly published in Allorge (1921: 606). Therefore, the name 'Callitricho-Batrachion' is validly published in Den Hartog \& Segal (1964). However, in the footnote, the authors clearly consider the alliance Batrachion fluitantis Neuhäusl 1959 as a suballiance of their new alliance. Therefore, ICPN art. 27b applies and the earliest name Batrachion fluitantis Neuhäus1 1959 has the priority (ICPN art. 25) over the name Callitricho-Batrachion Den Hartog \& Segal 1964 which is a superfluous name (ICPN art. 29c). 


\section{Ranunculion peltati}

The name 'Ranunculion peltati' is mentioned in SCHAMINÉE \& al. $(1990: 11,14)$ without an indication of being a new name. The alliance includes two associations such as the 'Hottonietum palustris' and the 'Callitricho-Ranunculetum hederacei'. No authority is given for these two names, nor relevés and, apparently, no bibliographical reference to published relevés. However, at p. 14, SCHAMINÉE \& al. say that the Ranunculion peltati is close to the Callitricho-Batrachion in WesthofF \& Den HeLd (1969) to whom an unambiguous reference is made in the bibliography. They also indicate for the two associations included in the alliance that the 'Hottonietum palustris' is a synonym of the 'Callitricho-Hottonietum' and that the content of the 'Callitricho-Ranunculetum hederacei' is something different from the 'Ranunculetum hederacei' retained by Westhoff and Den Held but without providing further information. Therefore, there is an indirect bibliographical reference to the 'Hottonietum palustris' that is the only element forming the original diagnosis of the name 'Ranunculion peltati'. In WeSTHOFF \& Den Held (1969: 56), there is the name 'Callitricho-Hottonietum (R. Tx. 1937 p.p.) Segal 1965 ' with an unambiguous reference to SEGAL (1965) in the bibliography. In SEGAL (1965: 65) there is the name 'Callitricheto-Hottonietum (TÜXEN 1937)' with an unambiguous bibliographical reference to TÜXEN (1937) where, at p. 49, there is the name 'Hottonia palustris-Ass. Tx. 1937. (prov.)' with a synoptic table of ten relevés. Thus, the name 'Callitricho-Hottonietum Tüxen ex Segal 1965 ' is validly published. However, the name-giving taxon Ranunculus peltatus does not occurr in Tüxen's synoptic relevé and the name 'Ranunculion peltati' is not validly published in SCHAMINÉE \& al. (1990) (ICPN art. 3f).

In SCHAMINÉE \& al. (1995: 99), the alliance 'Ranunculion peltati Schaminée, Lanjouw et Schipper 1990' contains four associations. For three of them there is an unambiguous bibliographical reference to their original diagnosis where they are validly published such as 'Callitricho-Hottonietum Tüxen ex Roll 1940 (sub nomine Hottonietum palustris)', 'Ranunculetum hederacei Schnell 1939' and 'Callitricho hamulatae-Ranunculetum fluitantis Oberdorfer 1957'. However, no type being indicated for the alliance, the name 'Ranunculion peltati Schaminée, Lanjouw et Schipper' remains invalidly published in SCHAMINÉE \& al. (1995) (ICPN art. 5).

Remark about the Hottonietum palustris. At the pages 583-588, RoLL (1940) mentions only a 'Hottonia palustris-Assoziation Tüxen' with several relevés and refers explicitly the association to p. 49 in Tüxen (1937). The name 'Hottonia palustrisAssoziation' being fully accepted and no more provisionally (as it is in TÜXEN, 1937), the correct citation of the association is Hottonietum palustris Tüxen ex Roll 1940. In SEgal (1965) the name 'Callitricheto-Hottonietum (Tüxen 1937)' [recte 'Callitricho-Hottonietum Tüxen ex Segal 1965'] is a later synonym of the name Hottonietum palustris Tüxen ex Roll 1940.

\section{Lemno-Callitrichion}

The new name 'Lemno-Callitrichion' is invalidly published in PASSARGE (1992: 516) because it is not clear from which species of the genus Callitriche it is formed (ICPN art. $3 \mathrm{~g}$ ). For the same reason the name 'LemnoCallitrichion Passarge 1992' would be also invalidly published in PASSARgE (1996).

\section{Nelumbion nuciferae Losev et Golub ex Mucina et Theurillat all. nov. hoc loco \\ (Potamogetonetalia, Potamogetonetea)}

SynONYM: 'Nelumbion nuciferae' Losev et Golub in Golub, Losev et Mirkin 1991 nom. inval. (ICPN art. 2b).

TYPE: Holotypus hoc loco: Nelumbetum nuciferae Golub ex Theurillat et Mucina in Theurillat et al. 2015 (see below).

Diagnostic SPECIES: Nelumbo nucifera.

Nomenclature: Golub \& al. (1991: 33) described the 'Nelumbion Losev et Golub' and assign here only one association - the Nelumbetum nuciferae, and attribute this association to ChugunOva-Sakharova (1924). 
However, when describing the plant community with Nelumbo nucifera, ChugunOva-SAKHAROva (1924: 181) used the rank of 'formation' (Russian school) and not that of an association (ICPN art. 3c). In addition, there is no indication of any quantitative or semi-quantitative quantities (species cover or similar) in the sense of the ICPN art. 7 for the species, although the author used only qualitative information (singularly, little, a large amount, very much). Therefore, there is no valid publication of the name Nelumbetum nuciferae in CHugunOvaSAKHAROVA (1924), unlike supposed by GoluB \& al. (1991). As a consequence, the name Nelumbion is invalidly published in GoLUB \& al. (1991). Despite there is a table presented on page 35 in GoluB \& al. (1991) containing four relevés of the 'Nelumbetum nuciferae', this association has not been clearly indicated as new and there is not a type relevé assigned as well (ICPN art. 5).

Here we validate the name Nelumbetum nuciferae Golub ex Theurillat et Mucina ass. nov. hoc loco and state that the original diagnosis of the name is the Table 13 in Golub \& al. (1991), selecting relevé 1 in that table as the holotypus hoc loco. Consequently, we validate the name 'Nelumbion Losev et Golub in Golub, Losev et Mirkin 1991' by designating the validated Nelumbetum nuciferae as the type of the alliance. Nelumbo nucifera is the diagnostic species of both the association and the alliance. Although Nelumbo is indeclinable (WeBER \& al., 2000: 760), it is preferable to use Nelumbion than 'Nelumboion' (see Theurillat \& Moravec, 1994: 401), as in an analogous case of 'Mugion' or 'Mugetum' based on Pinus mugo.

\section{VALIDATIONS OF THE NAME OF A SYNTAXON OF THE SCHEUCHZERIO- CARICETEA FUSCAE}

Caricion viridulo-trinervis Julve ex Hájek et Mucina all. nov. hoc loco

(Caricetalia davallianae, ScheuchzerioCaricetea fuscae)
Validated name: Caricion viridulae ssp. viridulae var. pulchello-trinervis Julve 1993 (JULVE 1993: 73; original form), (ICPN art. 5).

Holotypus hoc loco: Carici trinervisSchoenetum nigricantis de Foucault 2008 (DE Foucault 2008: 45).

Synonyms: Caricion pulchello-trinervis de Foucault 1984' (phantom); Caricion scandinavicae-trinervis Julve 1989 (ICPN art. 1), 'Caricion viridulae ssp. viridulae var. pulchellotrinervis (de Foucault 1984) Julve 1989‘ (phantom); 'Caricion pulchello-trinervis de Foucault ex Julve 1989' (phantom); 'Caricion viridulae ssp. viridulae var. pulchello-trinervis Julve 1993 ' nom. inval. (ICPN art. 5).

Character taxa: Carex trinervis, C. viridula, Gentianella uliginosa, Salix repens subsp. dunensis.

Differential taxa of the alliance (against the other alliances of the order): Agrostis stolonifera subsp. gaditana, Anagallis tenella, Blackstonia perfoliata, Carex punctata, Calamagrostis epigejos, Carex arenaria, Isolepis setacea, Leontodon saxatilis, Oenanthe lachenalii, Plantago uniflora, Pullicaria dysenterica, Ranunculus flammula, Samolus valerandii, Teucrium scordium.

The Caricion viridulo-trinervis comprises short-lived, yet not annual, low-sedge vegetation of wet, phosphorus-limited dune slacks of the winter-mild Atlantic coasts of Western Europe. Its species composition comprises (1) character taxa such as Carex trinervis, $C$. viridula (syn. C. scandinavica E. W. Davies; C. viridula subsp. pulchella in a narrow taxonomic sense), Gentianella uliginosa, Salix repens subsp. dunensis that are calcareous-fen species with the optimum in the Caricion davallianae alliance, (2) other fen species of the ScheuchzerioCaricetea fuscae (Dactylorhiza incarnata, Eleocharis quinqueflora, Epipactis palustris, Hydrocotyle vulgaris, Liparis loeselii, Parnassia palustris, Pedicularis palustris, Schoenus nigricans, Spiranthes aestivalis, Valeriana dioica), (3) subhalophytic and halophytic elements (Carex disticha, Centaurium littorale, C. pulchellum, Glaux maritima, Samolus 
valerandii), (4) species of temporary and disturbed wetlands (Isolepis setacea, Plantago uniflora, Sagina nodosa), (5) generalist grassland and wetland species (Calamagrostis epigejos, Calystegia sepium, Potentilla anseri$n a$ ) and (6) a group of species typical of the Holoschoenetalia (Agrostis stolonifera subsp. gaditana, Blackstonia perfoliata, Carex punctata, J. subnodulosus, Juncus articulatus, Leontodon saxatilis, Mentha aquatica, Oenanthe lachenalii, Pullicaria dysenterica, Teucrium scordium). The unique species combination, the high representation of grasses, the broad-leaved herbs and short-lived species as well as the poor representation of typical fen bryophytes makes this vegetation different from the rest of the Caricetalia davallianae. Using discriminant analysis, JIMÉNEZ-ALFARO \& al. (2014) found no support for the inclusion of dune slack vegetation into the Caricion davallianae, even when this alliance was defined broadly and included also boreal topogenous calcareous fens and arcto-alpine spring fens.

The name of the alliance (in several variations) was repeatedly suggested by Julve (JULVE 1989, 1993), but no description was valid so far. De Foucault (2008) included this vegetation into the Hydrocotylo vulgaris-Schoenion nigricantis - a unit comprising a wider range of calcareous fens of oceanic Europe (as a suballiance of its own right - the Caricenion pulchellotrinervis de Foucalt 2008). The type association of the Hydrocotylo vulgaris-Schoenion nigricantis represents purely inland fens with species composition corresponding well to the Caricion davallianae Klika 1934 and it does not display specific features of the Caricion viridulo-trinervis as mentioned above. In order to recognise the fen dune slack vegetation, we validate the only efficiently published name used for this vegetation so far - the one suggested by JuLVE (1993). Biogeographically the Caricion viridulo-trinervis is an Atlantic analogon to some communities of the Holoschoenetalia (TschOU, 1948; BRAUNBLANQUET \& al., 1952).

\section{ACKNOWLEDGEMENTS}

We greatly acknowledge the help of the following institutions and colleagues, respectively, in providing less accessible literature: the library of the Conservatoire et Jardin botaniques of the City of Geneva, the Conservatoire botanique national of Bailleul, Helga Bültmann, Nicolas Fumeaux and Séverine Peckeu.

\section{REFERENCES}

Allorge, P. —1921 - Les associations végétales du Vexin français - Rev. Gén. Bot. 33: 481-543, 589-652, 708751, 792-810, pl. 481-416.

Braun-Blanquet, J., Roussine, N. \& Nègre, R. - 1952Les groupements végétaux de la France méditerranéenne - Centre National de la Recherche Scientifique, Paris, FR.

Chugunova-Sakharova, N.V. - 1924- Nekotorye rezul'taty issledovanii lotosa Nelumbo nucifera v VolzhskoKaspiiskom regione - Russk. Gidrobiol. Zhurn. 3 (810): 173-199.

De Foucault, B. 2008: Validation nomenclaturale de syntaxons inédits ou invalides - J. Bot. Soc. Bot. France 43: 43-61

Den Hartog, C. —1963 - Enige waterplantengemeenschappen in Zeeland - Gorteria 1: 155-164.

Den Hartog, C. \& Segal, S. - 1964-A new classification of the water-plant communities - Acta Bot. Neerl. 13: 367-393.
Géhu, J.M. —1961-: Les groupements végétaux du bassin de la Sambre française - Vegetatio 10: 69-148, 161-208, 257-372.

Golub, V.B., Losev, G.A. \& Mirkin, B.M. —1991Aquatic and hygrophytic vegetation of the Lower Volga valley - Phytocoenologia 20: 1-63.

Jiménez-Alfaro, B., Hájek, M., Ejrnaes, R., Rodwell, J., Pawlikowski, P., Weeda, E.J., Laitinen, J., Moen, A., Bergamini, A., Aunina, L., Sekulová, L., Tahvanainen, T., Gillet, F., Jandt, U., Dítě, D., Hájková, P., Corriol, G., Kondelin, H. \& Díaz, T.E. —2014- Biogeographic patterns of base-rich fen vegetation across Europe Appl. Veg. Sci. 17: 367-380.

Julve, P. — 1989 - Etude phytosociologique et cartographie de la végétation de la réserve nationale de OyePlage - Centr. Rég. Phytosoc., Bailleul.

Julve, P. - 1993 - Synopsis phytosociologique de la France (communautés de plantes vasculaires) Lejeunia 140: 1-160. 
Koch, W. -1926- Die Vegetationseinheiten der Linthebene unter Berücksichtigung der Verhältnisse in der Nordostschweiz — Jahrb. St. Gall. Naturwiss. Ges. 61(2): 1-146.

Libbert, W. - 1940 - Pflanzensoziologische Beobachtungen in Schleswig-Holstein im Juli 1939 Repert. Spec. Nov. Regni Veg. Beih. 121: 92-130.

Mucina, L., Bültmann, H., Dierßen, K., Theurillat, J.P., Raus, T., , Čarni, A., Šumberová, K., Willner, W., Dengler, J., Gavilán, R.G., Chytrý, M., Hájek, M., Di Pietro, R., Lakushenko D., Pallas, J., Daniëls, F.J.A., Bergmeier, E., Santos Guerra, A., Ermakov, N., Valachovič, M., Schaminée, J.H.J., Lysenko, T., Didukh, Y.P., Pignatti, S., Rodwell, J.S., Capelo, J., Weber, H.E., Solomeshch, A., Dimopoulos, P., Aguiar, C., Hennekens, S.M. \& Tichý, L. —submittedVegetation of Europe: Hierarchical floristic classification system of vascular plant, bryophyte, lichen, and algal communities - Appl. Veg. Sci. (submitted).

Neuhäusl, R. —1959- Die Pflanzengesellschaften des südöstlichen Teiles des Wittingauer Beckens — Preslia 31: 115-147.

Oberdorfer, E. —1957— Süddeutsche Pflanzengesellschaften - Pflanzensoziologie 10: 1-564.

Passarge, H. - 1964- Pflanzengesellschaften des nordostdeutschen Flachlandes 1 - G. Fischer Verlag, Stuttgart.

Passarge, H. —1978 - Übersicht über mitteleuropäische Gefäßpflanzengesellschaften — Feddes Repert. 89: 133-195.

Passarge, H. - 1992 - Mitteleuropäische Potamogetonetea I - Phytocoenologia 20: 489-527.

Passarge, H. - 1996- Pflanzengesellschaften Nordostdeutschlands. I. Hydro- und Therophytosa Cramer, Stuttgart.

Rivas-Martínez, S., Díaz, T.E., Fernández-González, F., Izco J., Loidi J., Lousã, M. \& Penas, A. -2002-
Vascular plant communities of Spain and Portugal. Addenda to the syntaxonomical checklist of 2001 Itinera Geobot. 15: 5-922.

Roll, H. -1940- Holsteinische Tümpel und ihre Pflanzengesellschaften - Arch. Hydrobiol. Suppl. 10: 573-630.

Sauer, F. - 1937- Die Makrophytenvegetation ostholsteinischer Seen und Teiche - Arch. Hydrobiol. Suppl. 6: 431-592.

Schaminée, J.H.J., Lanjouw, B. \& Schieper, P. —1990Een nieuwe indeling van de waterplantengemeenschappen (Potametea) in Nederland - Stratiotes 1: 5-16.

Schaminée, J.H.J., Weeda, E.J. \& Westhoff, V.-1995De Vegetatie van Nederland. 2. Plantengemeenschappen van wateren, moerassen en natte heiden - Opulus Press, Uppsala.

Schnell, F.H. - 1939 - Die Pflanzenwelt der Umgebung von Lauterbach (Hessen) - Feddes Repert. Beih. 112: 1-106.

Segal, S. - 1965- Een vegetatieonderzoek van de hogere waterplanten in Nederland - Wetensch. Meded. Kon. Ned. Natuurhist. Ver. 57: 1-80.

Tchou, Y.-T. - 1948 - Études écologiques et phytosociologiques sur les forêts riveraines du Bas-Languedoc (Populetum albae) - Vegetatio 1: 2-28.

Theurillat, J.P. \& Moravec, J. -1994- Index of new names of syntaxa published in 1991 - Folia Geobot. Phytotax. 29: 385-412.

Tüxen, R. - 1937- Die Pflanzengesellschaften Nordwestdeutschlands - Mitt. Flor.-Soziol. Arbeitsgem. 3: 1-170.

Weber, H.E., Moravec, J. \& Theurillat, J.P. -2000International Code of Phytosociological Nomenclature. 3rd edition - J. Veg. Sci. 11: 739-768.

Westhoff, V. \& Den Held, A. J. (Eds.) -1969Plantengemeenschappen in Nederland - Thieme, Zutphen. 